\title{
RETROSPECTIVE ANALYSIS OF PONTICULUS POSTICUS IN INDIAN ORTHODONTIC PATIENTS-A LATERAL CEPHALOMETRIC STUDY
}

\author{
Gupta Mudit ${ }^{1}$, Kandula Srinivas ${ }^{2}$, Reddy Satheesha $\mathrm{BH}^{3}$
}

\begin{abstract}
BACKGROUND: The lateral cephalogram is the most common diagnostic radiograph used in clinical orthodontics. Significant cervical spine pathology can be detected on the routine lateral cephalogram. The aim of this study is to sensitize clinicians for examining the cervical area of lateral cephalogram carefully and thus record anatomical variations.

MATERIALS AND METHODS: The presence and types of ponticuli posticus were investigated on 650 lateral cephalograms which were randomly selected from archived records at AECS Maaruti College of Dental Sciences \& Research Centre, Bangalore

RESULTS: The prevalence rate of Ponticulus Posticus in our study was found to be 11.1\%. Though there was slight female predominance of $11.7 \%$ as compared to $10.4 \%$ in males, difference was not statistically significant.

CONCLUSION: Ponticulus posticus is a common anomaly in the Indian population. If any such anomaly is detected or suspected, it must be documented in the patient's health record and specialist consultation must be sought. The lateral cephalogram must thus be considered as one of the baseline screening tool for detecting anomalies and pathology in the cervical spine region.

KEYWORDS: Ponticulus posticus, kimmerle anomaly, lateral cephalogram, arcuate foramen, migraine
\end{abstract}

DOI: http://dx.doi.org/10.4314/ejhs.v24i4.2

\section{INTRODUCTION}

The lateral cephalogram is the most common diagnostic radiograph used in clinical orthodontics. The cervical spine area present in lateral cephalograms is, however, generally omitted in cephalometric tracings. Although the skeletal maturation evaluation using cervical vertebrae and its modified version, cervical vertebrae maturation index (CVMI), is now commonly used to interpret the growth potential of young patients (1). Inadequate attention is paid to the radiological anatomy of this region with a view to identifying pathology. Significant cervical spine pathology can be detected on the routine lateral cephalogram $(2,3)$. Since "the eye sees what the mind knows", one of the aims of this article is to sensitize clinicians and radiologist to "see" the cervical spine and be equipped to identify departures from normal anatomy.

The Latin meaning of ponticulus posticus is "little posterior bridge", which describes an anomalous malformed bony bridge between the posterior portion of the superior articular process and the posterolateral portion of the superior margin of the posterior arch of the atlas. The normal atlas is a ring-like structure consisting of two lateral masses connected by a short anterior arc and a longer posterior arch. It is the widest cervical vertebra, with its anterior arch

\footnotetext{
${ }^{1}$ Uttaranchal Dental \& Medical Research Institute, Oral Medicine \& Radiology, Dehradun, Uttarakhand, India ${ }^{2}$ Best Dental Science College, Oral Medicine \& Radiology, Madurai, Tamil Nadu, India

${ }^{3}$ Maaruti College of Dental Sciences \& Research Centre, Oral Medicine \& Radiology, Bangalore, Karnataka, India Corresponding Author: Gupta Mudit, Email: mudit_dentist@rediffmail.com, mudit@dr.com
} 
approximately half as long as the posterior arch. The posterior arch corresponds to the laminae of other vertebrae. On its upper surface is a wide groove for the vertebral artery and the first cervical nerve. In $1-15 \%$ of the population, a bony arch may form thereby converting this groove into a foramen through which these structures pass. This bony arch is known as the ponticulus posticus (4). Historically, ponticulus posticus has been referred to by many names including pons posticus, arcuate foramen, foramen arcuale, retroarticular vertebral artery ring, Kimmerle anomaly, foramen atlantoideum, foramen sagitale, canalis arteriae vertebralis, and retroarticular canal of the atlas (5-8).

The potential clinical significance of ponticulus posticus is controversial because the majority of patients with this finding are asymptomatic (5). Some studies have determined that patients with ponticulus posticus do not have a high chance of experiencing adverse effects from cervical adjustments related to its presence (9). However, symptoms that may be associated with ponticulus posticus include migraine without aura (10), chronic tension type of headache (11), vertigo, diplopia, and neck pain (12). It has even been suggested that ponticulus posticus may contribute to vertebral artery compression, vertebro-basilar insufficiency, or vertebral artery dissection. It must also be taken into account during the immobilization of the cervical spine with lateral mass fixation in $\mathrm{C} 1$. Young et al reported that mistaking the ponticulus posticus for a broad posterior arch of the atlas during $\mathrm{C} 1$ lateral mass screw placement could cause injury to the vertebral artery (13).

Although we are not directly concerned with the management of cervical spine anomalies, we do have an obligation, as healthcare professionals, to record any such findings that may hold importance for the patients 'overall health. Considering the growing clinical importance of this entity, we need to understand the morphological features and the prevalence of this anomaly. The lateral cephalogram is a useful screening tool for detection of this anomaly.

There appear to be very few studies on the prevalence or morphological characteristics of ponticulus posticus in an Indian population. Therefore, we investigated the prevalence and morphological features of ponticulus posticus in an Indian population comprising patients reporting to our institute for orthodontic treatment who were all healthy and free of any systemic or musculoskeletal problems.

\section{MATERIALS AND METHODS}

The study was done in June 2012 at AECS Maaruti College of Dental Sciences \& Research Centre, Bangalore. The study was approved by the ethical committee of the institution and it was carried out in the Department of Oral Medicine and Radiology. All the procedures were in accordance with ethical standards of the committee on human experimentation of the institution as well as the Helsinki Declaration of 1975 as revised in 1983. The machine which was used to take lateral cephalograms was VATECH PaX 400-C (Vatech Global, Gangnam Gu, Korea).

Lateral cephalograms were retrieved from the archives and examined for ponticulus posticus. The study population was Indian (Dravidian) in origin belonging to South Karnataka Region. Lateral cephalograms with poor visualization of the posterior arch of the atlas due to overlapping of the mastoid process or the occiput were excluded. Patients who reported with congenital anomalies such as cleft lip and palate were not included in the study. Patients with other syndromic conditions involving the craniofacial region were also excluded. Lateral cephalograms of 650 patients, comprising 290 males and 360 females, were examined. The mean age was 20.2 years (range 12-25 years). The distribution of the sample by age and sex is presented in Table 1.

Table 1: Distribution of Patients

\begin{tabular}{llll}
\hline Sex & $\begin{array}{l}\text { No. of } \\
\text { Patients }\end{array}$ & Age Range & $\begin{array}{l}\text { Mean } \\
\text { Age }\end{array}$ \\
\hline Males & 290 & $12-25$ years & 19.9 \\
Females & 360 & $12-25$ years & 20.5 \\
Total & 650 & $12-25$ years & 20.2 \\
\hline
\end{tabular}

The images were viewed on a flat screen TFTLCD monitor (Thin Film Transistor-Liquid Crystal Display) with a resolution of 2906 x 2304 pixels in JPEG (Joint Photographic Experts Group) format with 24-bit grayscale. Each radiograph was carefully inspected for the presence of a ponticulus posticus and whether it was complete or partial. During initial 
examination, all lateral cephalograms were observed independently by two of the authors. To eliminate any error, 100 randomly selected lateral cephalograms were re-examined separately by the same two authors a month after initial examination. All the data were entered in Microsoft Excel 2007 and subjected to statistical analysis. Chi square test with Yates correction was used to analyze the differences between males and females regarding the presence of ponticulus posticus (Table 2).

Table 2: Prevalence of ponticulus posticus as observed in our study

\begin{tabular}{l|lcc}
\hline Type & Male & Female & 'p' value \\
\hline Complete & $8(2.8 \%)$ & $11(3.1 \%)$ & 0.8232 \\
Partial & $22(7.6 \%)$ & $31(8.6 \%)$ & 0.7410 \\
\hline Total & $30(10.4 \%)$ & $42(11.7 \%)$ & 0.6832 \\
\hline
\end{tabular}

\section{RESULTS}

Analysis of 650 lateral cephalograms revealed prevalence rate of ponticulus posticus (both complete and partial) as $11.1 \%$ in the population studied. Although slight female predominance is seen, it is not statistically significant $(p>0.05)$.

There was complete agreement between the two authors at both the first and second examination and also intra-observer agreement was complete at two different examinations. The details of results are given in Figure 1 below and Table 2 above.

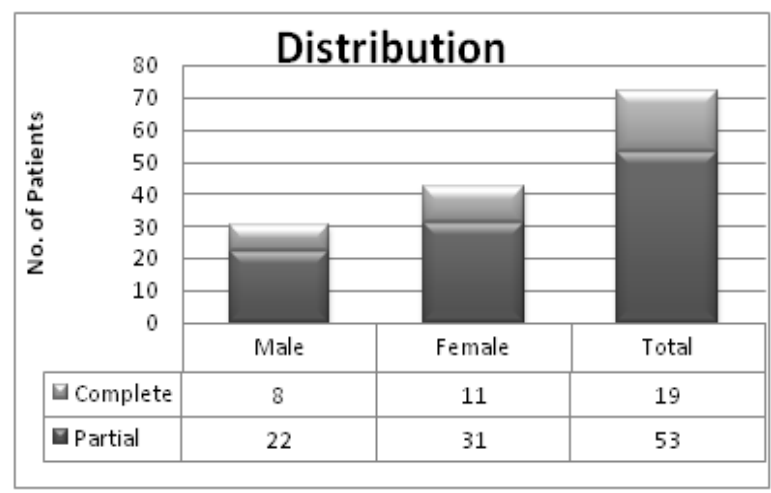

Fig. 1: Column chart showing details of results of the study
The varied appearance of ponticulus posticus in our study as seen on lateral cephalogram is shown in Figure II-IV (cropped images of lateral cephalograms).

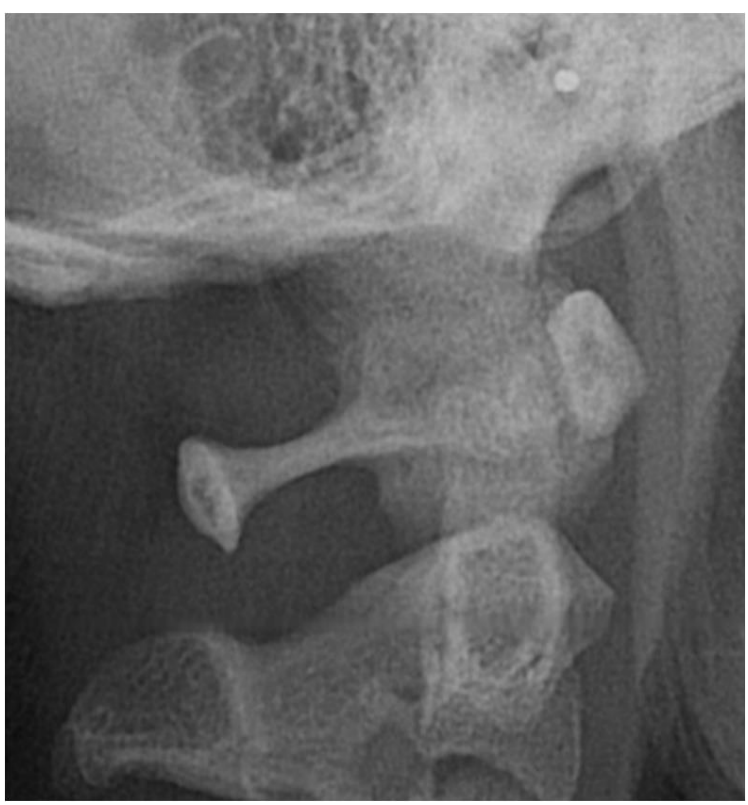

Fig. 2: Cropped image of a normal lateral cephalogram

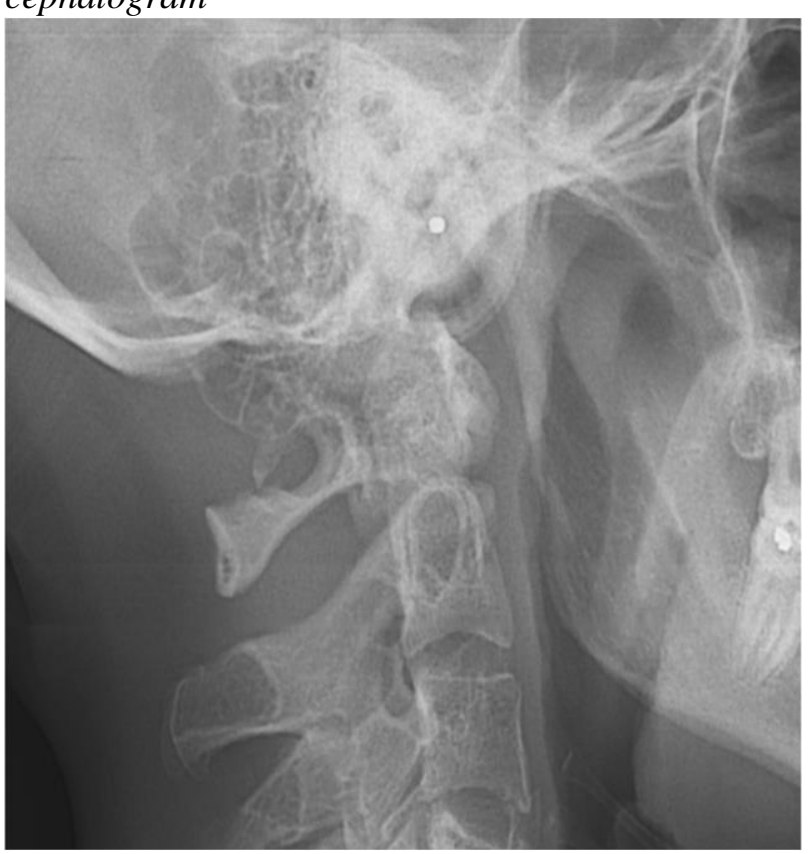

Fig.3: Cropped image of a lateral cephalogram showing partial ponticulus posticus 


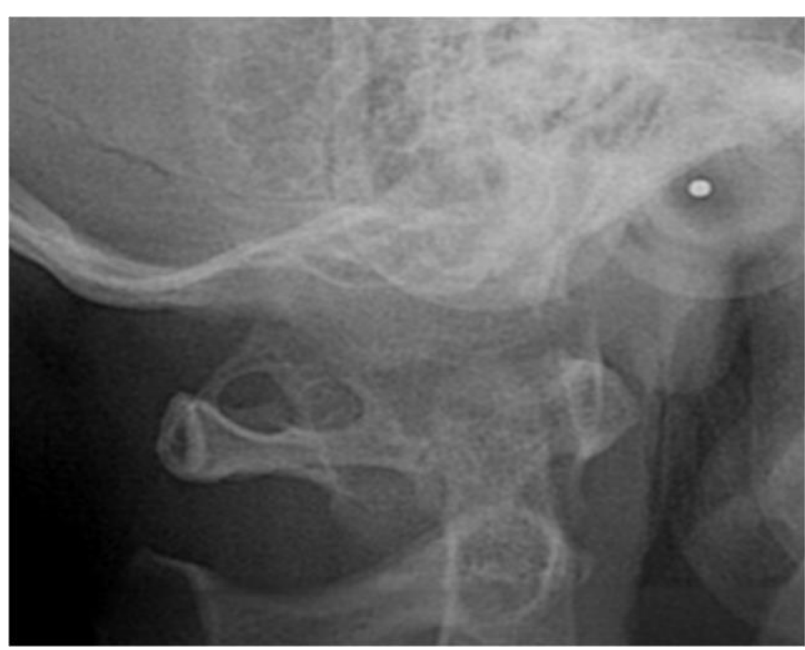

Fig.4: Cropped image of a lateral cephalogram showing complete ponticulus posticus

\section{DISCUSSION}

In the western population, the prevalence of ponticulus posticus has been reported to be between $5.1 \%$ and $37.8 \%$ (13,14). Complete ponticulus posticus has been found to be between $2.6 \%$ and $14.3 \%$ in radiological and between $3.4 \%$ and $15 \%$ in osteological studies (15). In our study, complete ponticulus posticus was seen in $2.95 \%$ of the subjects. Female predominance (14) has been described more often, and a similar pattern is seen in our study. Numerous studies have reported a higher prevalence of cervical spine anomalies in cleft lip and palate patients.

In a study done by V Sharma et al (16) on Indian Orthodontic patients, the authors found prevalence of complete ponticulus posticus as $4.3 \%$, which is higher than ours $(2.95 \%)$ and they also found male $(5.33 \%)$ predominance over female $(3.76 \%)$ in the population studies. In our study, complete ponticulus posticus is seen in $2.8 \%$ of males and $3.1 \%$ of females. The difference could be attributed to the different origin of population in both the studies.

In our study, a total prevalence of $11.1 \%$ is seen in the population of age group of 12- 25 years. Although slight female predominance is seen, it is not statistically significant $(\mathrm{F}: \mathrm{M}=11.7$ : 10.4). Similar findings were seen in a study by Shilling et al (17) and Yong Jae Cho (18).

In a study by Yong Jae Cho (18) on Koreans, prevalence of ponticulus posticus was $15.5 \%$ when imaging modality used was 3-D CT scan and in the same study group the prevalence rate decreased to $6.95 \%$ when plain radiograph analysis was done. This increase in prevalence as compared to our study could be ascribed to the type of screening modality used i.e. higher diagnostic value of 3-D CT as compared to plain radiography.

In a study by P. Kuhta et al (19), the prevalence of ponticulus posticus was reported to be $45.9 \%$, which is much higher than ours. This could be attributed to the age of the patients included in the study. The calcification of the bony bridge progresses over time from an incomplete bony arch to a complete ossification as has been described by Paraskevas et al (20).

In a study done on Caucasians by Kendrick et al (21) it was reported prevalence of ponticulus posticus to be around $15.8 \%$, which is slightly higher than ours. This difference could be due to different ethnicity of the study groups.

Considering the grave complications that can arise from overlooking this anomaly in cervical spine surgery and other cervical spine interventions and the ease with which it can be avoided, if identified correctly, we need to emphasize identification of the ponticulus posticus on routine lateral cephalograms. Recently, Leonardi R et al (22) have concluded in their study that calcification of the atlanto-occipital ligament should be considered as one of the major criteria for nevoid basal cell carcinoma syndrome diagnosis.

Also, as there is a positive co-relation between migraine, chronic tension type of headache and the presence of ponticulus posticus, and again both of these orofacial pain conditions are seen as co-morbidity with TMJ disorders $(23,24)$. In all of these orofacial pain disorders, diagnosis is mostly based on history given by the patient, and to-date, there is no diagnostic test available which could be used to assess the risk factors associated with these disorders. Thus, if such correlation is proven, then probably in the future, screening of lateral cephalogram for presence of ponticulus posticus could be one of the baseline investigations.

Since our study was retrospective, we did not know about the pain status of the patients; so, more studies are needed to be done especially on symptomatic patients to further prove this correlation. 
In conclusion, the study showed that ponticulus posticus is not an uncommon anomaly in the Indian population. Since this anomaly has been associated with presence of orofacial pain like migraine, further studies should be done on different populations with larger sample sizes, especially on symptomatic patients, to further prove this correlation. We suggest that, during routine radiographic examination, if ponticulus posticus is detected, it should be documented in patients' health record and if patients are symptomatic, further investigation should be sought for.

\section{REFERENCES}

1. Hassel B, Farman AG. Skeletal maturation evaluation using cervical vertebrae. Am J Orthod Dentofac Orthop 1995; 107: 58-66.

2. Baccetti T, Franchi L, McNamara JA Jr. The cervical vertebrae maturation $(\mathrm{CVM})$ method for assessment of optimal treatment timing in dentofacial orthopedics. Sem Orthod 2005; 11: 119129.

3. Soni P, Sharma V, Sengupta J. Cervical vertebral anomalies: incidental findings on lateral cephalograms. Angle Orthod 2008; 78: 176-180.

4. Ghanayem AJ, Paxinos O. Functional anatomy of joints, ligaments and disc. In: Clark CR (ed.) The cervical spine $\left(4^{\text {th }}\right.$ edn $)$. Philadelphia Lippincotth Williams and Wilkins, 2005, pp 46-54.

5. Yochum TR, Rowe LJ. Essentials of skeletal radiology. 3rd ed. Baltimore: Lippincott Williams and Wilkins; 2005. p. 269-70.

6. Le Minor JM, Trost O. Bony ponticles of the atlas $(\mathrm{C} 1)$ over the groove for the vertebral artery in humans and primates:polymorphism and evolutionary trends. Am J Phys Anthropol 2004;125(1):16-29.

7. Crowe HS. The ponticulus posticus of the atlas vertebra and its significance. Upper Cerv Monogr 1986;4(1):1-5.

8. Mitchell J. The incidence and dimensions of the retroarticular canal of the atlas vertebra. Acta Anat 1998;163:113-20

9. Haynes M, Cala L, Melsom A, Mastaglia F, Milne N, McGeachie J. Posterior ponticles and rotational stenosis of vertebral arteries. A pilot study using Doppler ultrasound velocimetry and magnetic resonance angiography. J Manipulative Physiol Ther 2003;28(5):323-9

10. Wight S, Osborne N, Breen AC. Incidence of ponticulus posterior of the atlas in migraine and cervicogenic headache. J Manipulative Physiol Ther 1999; 22: 15-20.

11. Ephrosyni Koutsouraki, Eugenia Avdelidi, Dimitrios Michmizos, Stella-Evangelia Kapsali, Vassiliki Costa, and Stavros Baloyannis. Kimmerle's Anomaly as a Possible Causative Factor of Chronic TensionType Headaches and Neurosensory Hearing Loss: Case Report and Literature Review. International Journal of Neuroscience 2010 120:3, 236-239

12. Lambarty BGH, Zivanovic S. The retroarticular vertebral artery ring of the atlas and its

13. Young JP, Young PH, Ackermann MJ, Anderson PA, Riew KD. The ponticulus posticus: implications for screw insertion into the first cervical lateralmass. J Bone Joint Surg Am 2005; 87: 2495-2498.

14. Stubbs DM. The arcuate foramen: variability in distribution related to race and sex. Spine 1992; 17: 1502-1504

15. Unur E, Erdogan N, U* lger H, Ekinci N, O* ztu“ rk O. Radiographic incidence of complete arcuate foramen in Turkish population. Erciyes Med J 2004; 26: 50-54

16. V Sharma, D Chaudhary, R Mitra.Prevalence of ponticulus posticus in Indian orthodontic patients. Dentomaxillofacial Radiology.2010; 39: 277-283

17. Schilling J, Schilling, A, Suazo GI. Ponticulus posticus on the posterior arch of atlas, prevalence analysis in asymptomatic patients. Int. J. Morphol., 28(1):317-322, 2010

18. Yong Jae Cho. Radiological Analysis of Ponticulus Posticus in Koreans. Yonsei Med J 50(1):45 - 49

19. Patricia K, John H, Laura G, Beth McDowell R, Perry R. The prevalence of posticus ponticus: retrospective analysis of radiographs from a chiropractic health center. J Chiropr Med. 2010 December; 9(4): 162-165.

20. Paraskevas, G.; Papaziogas, B.; Tsonidis, C. \& Kapetanos, G. Gross morphology of the bridges over the vertebral artery groove on the atlas. Surg. Radiol. Anat.2005;27(2):129-36. 
21. Kendrick GS, Biggs NL. Incidence of the ponticulus posticus of the first cervical vertebra between ages six to seventeen. Anat. Rec. 1963;145: 449-453.

22. Leonardi R, Santarelli A, Barbato E, Ciavarella D, Bolouri S, Härle F, Palazzo G, Lo Muzio L. Atlanto-occipital ligament calcification: a novel sign in nevoid basal cell carcinoma syndrome. Anticancer Res. 2010 Oct;30(10):4265-7.
23. Gonçalves DA, Camparis CM, Speciali JG, Franco AL, Castanharo SM, Bigal ME. Temporomandibular disorders are differentially associated with headache diagnoses: a controlled study. Clin J Pain. 2011 Sep;27(7):611-5.

24. Plesh O, Adams SH, Gansky SA. Selfreported comorbid pains in severe headaches or migraines in a US national sample. Headache. 2012 Jun;52(6):946-56. 